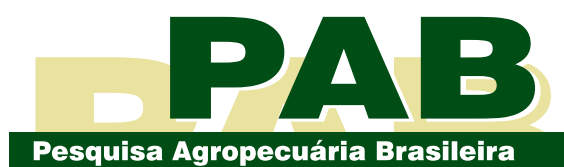

ISSN 1678-3921

Journal homepage: www.embrapa.br/pab

For manuscript submission and journal contents, access: www.scielo.br/pab
Plant Physiology/ Original Article

\section{Source-sink relationships of wheat plants obtained by the application of systemic herbicides}

Abstract - The objective of this work was to evaluate the potential of solute translocation among stems of wheat (Triticum aestivum), by the application of the systemic herbicides clethodim and glyphosate. The experiments were carried out in greenhouse conditions, using wheat cultivars with contrasting potential for tillering, during the winter of 2017 and 2018 in Southern Brazil. Clethodim was applied on isolated stems, to evaluate the potential translocation of solutes from the first three tillers. Translocation was evaluated by the yield parameters on stem ears not treated with clethodim. Glyphosate was used to evaluate the potential translocation of solutes from late tillers. Translocation was evaluated by the assimilation of carbon in stems without the glyphosate treatment. When applied on isolated primary tillers, clethodim reduced yield parameters only in treated stems, which shows that the assimilates were targeting the main sink, in detriment of the other organs. There was a decrease in net carbon assimilation in stems without the glyphosate treatment at the first visible node stage. Glyphosate applied on late tillers, at anthesis, reduced even more net carbon assimilation in nontreated stems of the primary tillers of the BRS Parrudo wheat cultivar (low tillering). Well-developed late tillers show higher potential of solute translocation to the whole plant than the poor-developed ones.

Index terms: Triticum aestivum, clethodim, glyphosate, tillering, transient sink.

\section{Relações entre fonte e dreno de plantas de trigo obtidas pela aplicação de herbicidas sistêmicos}

Resumo - O objetivo deste trabalho foi avaliar o potencial de translocação de solutos entre colmos de trigo (Triticum aestivum), por meio da aplicação dos herbicidas sistêmicos cletodim e glifosato. Os experimentos foram realizados em cultivo protegido, com cultivares contrastantes quanto ao potencial de perfilhamento, durante o inverno de 2017 e 2018, no Sul do Brazil. O cletodim foi aplicado em colmos isolados, para se avaliar o potencial de translocação a partir dos três primeiros perfilhos. A translocação foi avaliada, por meio dos parâmetros produtivos, em espigas de colmos não tratados com cletodim. O glifosato foi utilizado para avaliar o potencial de translocação a partir dos perfilhos tardios. A translocação foi avaliada por meio da assimilação de carbono, em colmos sem o tratamento com glifosato. Quando aplicado nos perfilhos primários isolados, o cletodim reduziu os parâmetros produtivos apenas em colmos tratados com o herbicida, o que mostra o direcionamento de assimilados para o dreno principal, em detrimento de outros órgãos. Houve decréscimo da assimilação de carbono em colmos sem o tratamento com glifosato, no estádio de primeiro nó visível. O glifosato aplicado a perfilhos tardios, na antese, reduziu ainda mais a assimilação de carbono em colmos primários não tratados da cultivar de trigo BRS Parrudo (baixo perfilhamento). Perfilhos tardios bem desenvolvidos apresentam maior potencial de translocação de solutos para o restante da planta do que os pouco desenvolvidos.

Termos para indexação: Triticum aestivum, cletodim, glifosato, perfilhamento, drenos transitórios. 


\section{Introduction}

Physiological and productive parameters of contrasting wheat cultivars have been addressed under various conditions, such as sowing dates and densities, plant nutrition, and environmental stresses (Duggan et al., 2005; Ruan et al., 2012; Mitchell et al., 2012, 2013; Guo \& Schnurbusch, 2015; Hendriks et al., 2016; Houshmandfar et al., 2019). Despite all these studies, it is still difficult to understand the interactions between the main stem and tillers for the source-sink relationship. The ability of wheat plants to remobilize assimilated carbon from stem into spike during the grain filling has been widely reported, especially in restricted environments (Ahmadi et al., 2009; Mitchell et al., 2013; Guo \& Schnurbusch, 2015; Dodig et al., 2017; Turek et al., 2018). However, the mobilization of reserves among stems of the same plant is less understood.

Long-distance transport between main stem and lateral shoots is well developed in dicotyledon (or dicot) species, such, that are more studied in relation to solute translocation (Slewinski et al., 2013). In these plants, xylem and phloem vessels establish a large network of translocation and communication throughout the plant structure (Lucas et al., 2013). The multistem structure of monocots, such as wheat, raises questions on the effectiveness of communication among stems of the same plant. It is well known that tillers are supported by the main stem with sugars, water, and nutrients, during the emission period, as a result of vascular connections (Alves et al., 2000). However, to be a transient sink of assimilates, senescent tillers would have to keep these vascular connections with the whole plant until the grain filling stage.

Source-sink relationship has been widely studied in the past decades, using increasingly improved tools (Turgeon \& Wolf, 2009; Dinant \& Lemoine, 2010; Lucas et al., 2013). Since phloem long-distance transport of solutes is dependent of vascular connections between source and sink organs, the application of systemic herbicides can be a useful tool to study the potential of solute translocation in plants. Clethodim is a phloem-mobile herbicide (Bromilow et al., 1990) that belongs to the cyclohexanedione chemical family of herbicides, which are potent inhibitors of the enzyme acetyl-coenzyme A carboxylase (ACCase, EC 6.4.1.2) (Burton et al., 1987). Glyphosate is also a phloem-mobile herbicide (Bromilow et al., 1990) that binds to and blocks the activity of the enzyme enolpyruvylshikimate-3-phosphate synthase (EPSP synthase, EC 2.5.1.19).

Clethodim and glyphosate show high mobility among plant organs of wheat plants (Nandula et al., 2007), as well as in other monocot species, such as Elytrigia repens (Tardif \& Leroux, 1991). However, such translocation was only shown at early stages of plant development.

The objective of this work was to evaluate the potential of solute translocation among stems of wheat, by the application of the systemic herbicides clethodim and glyphosate.

\section{Materials and Methods}

Two experiments were carried out in greenhouse conditions, in a randomized complete block design with $2 \times 4$ factorial arrangement and four replicates, during the winters of 2017 and 2018, in the experimental area of the Universidade Federal de Santa Catarina, on the Curitibanos campus, in Southern Brazil. The wheat cultivars BRS Guamirim (high tillering) and BRS Parrudo (low tillering) were used in both experiments as contrasting genotypes for tillering potential (Fioreze et al., 2019).

In 2017, the four experimental factors consisted of clethodim application to wheat plants on the primary tillers of nontreated plants, as well as on the main stem, first tiller, and second tiller (Figure 1). Clethodim Select $240 \mathrm{~g} \mathrm{~L}^{-1}$ EC (UPL, Itupeva, SP, Brazil) spray solution at $0.24 \mathrm{~g} \mathrm{~L}^{-1}$ was applied at the 10.5 stage (flowering) of Feeks scale (Large, 1954), on the first three leaves of the stem apex, using a brush paint.

In 2018, the four experimental factors consisted of glyphosate application to wheat plants on late tillers of nontreated plants, as follows: all tillers at the 6 stage (first node) of Feeks scale; all tiller at the 10.5 stage of Feeks scale; and on the two last tillers emitted at the 10.5 stage of Feeks scale (Figure 1). The spray solution of glyphosate (Crucial $540 \mathrm{~g} \mathrm{~L}^{-1} \mathrm{SL}$, Nufarm, Maracanaú, CE, Brazil), at $6.6 \mathrm{~g} \mathrm{~L}^{-1}$, was applied on the whole described tillers (on leaves), using a brush paint.

In both experiments, main stem and the first two (2017) or three (2018) emitted tillers, were considered as primary tillers. For 'BRS Guamirim', primary tillers were T0, T1, and T2, while for 'BRS Parrudo', primary tillers were T1, T2, and T3 (Masle 1985). Early after 
emergence, different classes of tillers were identified by colored cotton threads (primary tillers). All tillers emitted after that were considered as late tillers.

Plants were grown in $3.6 \mathrm{~L}$ plastic pots filled with Cambissolo Háplico típico, soil Brazilian classification by Santos et al. (2018), which corresponds to Inceptisol, with a clayey texture (550 $\mathrm{g} \mathrm{kg}^{-1}$ clay) limed with $1.51 \mathrm{~g} \mathrm{dm}^{-3}$ limestone. Soil was fertilized with $120 \mathrm{mg} \mathrm{dm}^{-3}$ potassium chloride $\left(60 \% \mathrm{~K}_{2} \mathrm{O}\right)$, and 2.16 $\mathrm{g} \mathrm{dm}^{-3}$ triple superphosphate $\left(42 \% \mathrm{P}_{2} \mathrm{O}_{5}\right)$. Side dressing $\mathrm{N}$ fertilization took place at every 15 days between emergence and anthesis, using urea $(45 \% \mathrm{~N})$ applied via solution $\left(25 \mathrm{mg} \mathrm{dm}^{-3} \mathrm{~N}\right)$ to reach $150 \mathrm{mg} \mathrm{dm}^{-3} \mathrm{~N}$. In each pot, five seed were sown at $3 \mathrm{~cm}$ soil depth. Ten days after seedling emergence, only one plant was kept growing in each pot.

At the maturity stage, clethodim-treated plants were collected to determine the yield parameters. Plants were separated in main stem, first tiller, second tiller, and late tillers, to study the effects of herbicide on yield parameters of nontreated stems. For each group, the length of rachis, number of fertile spikelets, number of grains, and mass of grains were evaluated. Additionally, the number of tillers and the number of fertile tillers were determined in control plants.

In glyphosate-treated plants, the net carbon assimilation was used as a tool to study the effects of the herbicide. Net carbon assimilation was measured every two days in the main stem, first, second, and third tillers, and late treated tillers (as well as nontreated plants), using a portable photosynthesis meter with opened system IRGA LI-6400xt (Licor Inc., Lincoln, NE, EUA). The measurements were interrupted as soon as the net carbon assimilation approached zero. As glyphosate killed the plants, yield parameters were not evaluated.

Data were subjected to the analysis of variance by the $\mathrm{F}$ test, at $5 \%$ probability. Means were compared by the Tukey's test, at $5 \%$ probability, using the Sisvar software (Ferreira, 2011) for clethodim-treated plants. Data on carbon net assimilation (glyphosate-treated plants) were plotted with the values of standard deviation.

\section{Results and Discussion}

Both wheat cultivars are contrasting for the potential of tiller emission (Figure 2). BRS Guamirim showed higher values of total number of tillers and number of viable tillers. The large number of productive tillers per plant is a consequence of the plant growing in pots, with no restrictions of water, nutrients, and solar radiation; therefore, there was a slight difference between the total number of tillers and the number of viable tillers per plant, for each cultivar.

There was no significant interaction between wheat cultivars and clethodim application for the productive
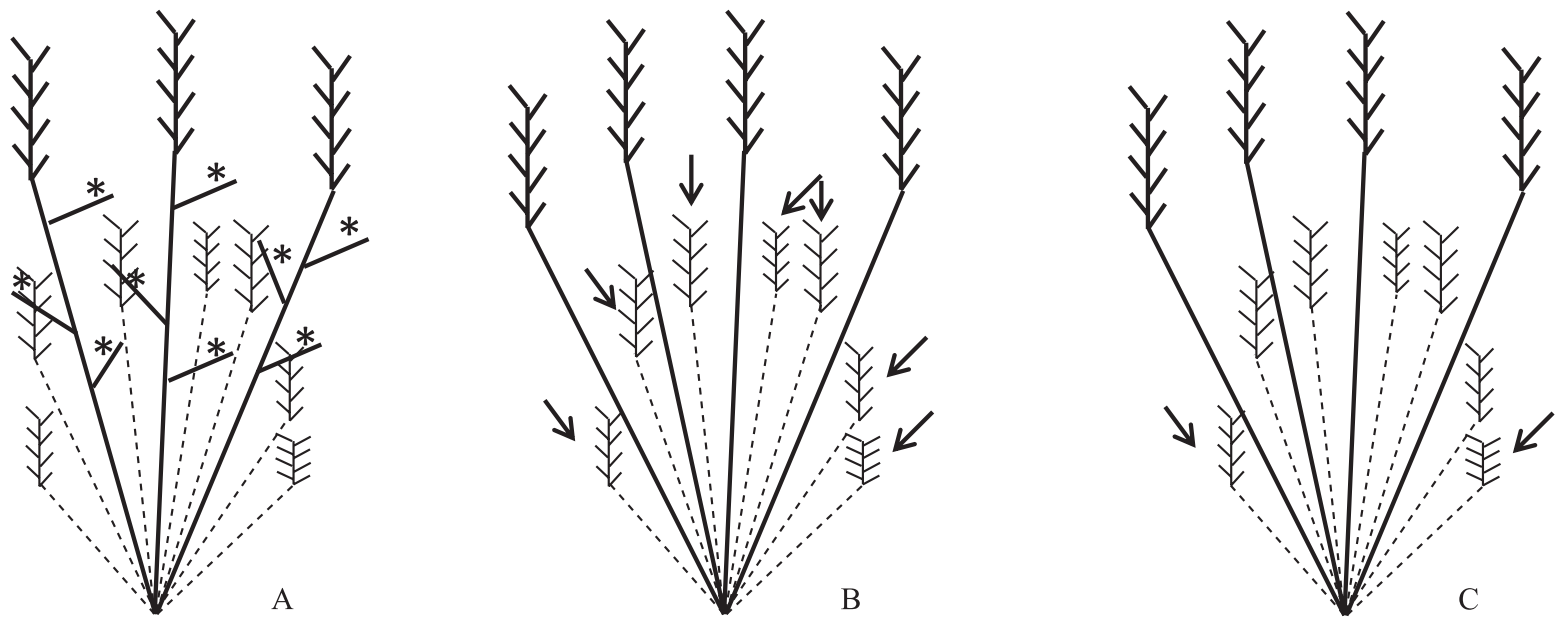

Figure 1. Wheat plant aerial part: solid lines represent primary tillers and dashed lines represent late tillers. Asterisks indicate the clethodim application on leaves of primary tillers (A). Arrows indicate the glyphosate application on all late tillers (B), or on two last tillers emitted (C). 
parameters of wheat spikes (Table 1). BRS Parrudo cultivar showed an individual potential of spike yield higher than that of BRS Guamirim cultivar due to the lower number of spikes per plant. Therefore, BRS Parrudo cultivar showed higher length of rachis, as well as higher number of fertile spikelets and higher number and mass of grains per spike, for both primary tillers and average of other spikes of the plant.

The effect of competition among tillers on the individual potential of spike yield in wheat plants was widely recorded. A high tiller emission results in limitations on the productive potential of spikes by wheat plants because of the competition for assimilates, water, and nutrients (Fioreze et al., 2019). Thus, limitations on the number of tillers per plant due either to mutations or even the manual removal of tillers improve the productive potential of wheat spikes (Duggan et al., 2005; Dreccer et al., 2013; Mitchell et al., 2013; Hendriks et al., 2016).

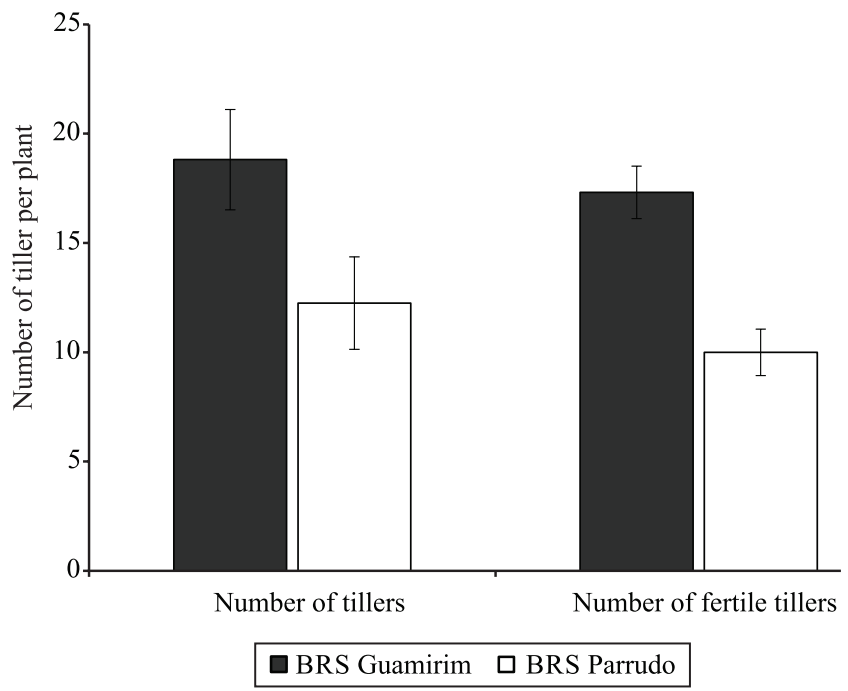

Figure 2. Number of tillers per plant, and number of fertile tillers per plant in BRS Guamirim and BRS Parrudo wheat (Triticum aestivum) cultivars. Vertical bars indicate standard deviation.

Table 1. Yield parameters for rachis length, number of fertile spikelets, number of grains, and grain mass per spike, in wheat (Triticum aestivum) cultivars affected by the clethodim application on primary tillers ${ }^{(1)}$.

\begin{tabular}{|c|c|c|c|c|c|c|c|c|}
\hline Treatment & $\mathrm{MC}$ & T1 & $\mathrm{T} 2$ & Average $^{(2)}$ & $\mathrm{MC}$ & $\mathrm{T} 1$ & $\mathrm{~T} 2$ & Average $^{(2)}$ \\
\hline Cultivar (C) & \multicolumn{3}{|c|}{ Rachis length (cm) } & \multicolumn{5}{|c|}{ Number of fertile spikelets per spike } \\
\hline BRS Guamirim & $10.2 \mathrm{~b}$ & $9.7 b$ & $9.8 \mathrm{~b}$ & $8.6 \mathrm{~b}$ & $13.3 \mathrm{~b}$ & $12.8 \mathrm{~b}$ & $14.9 \mathrm{~b}$ & $8.5 \mathrm{a}$ \\
\hline BRS Parrudo & $11.2 \mathrm{a}$ & $11.5 \mathrm{a}$ & $11.5 \mathrm{a}$ & $10.4 \mathrm{a}$ & $22.6 \mathrm{a}$ & $24.1 \mathrm{a}$ & $22.9 \mathrm{a}$ & $10.4 \mathrm{~b}$ \\
\hline $\mathrm{p}$-value of $\mathrm{F}$ test & 0.00 & 0.00 & 0.00 & 0.00 & 0.00 & 0.00 & 0.00 & 0.00 \\
\hline \multicolumn{9}{|l|}{ Treatment $(\mathrm{T})$} \\
\hline Control & 10.7 & 10.4 & 10.6 & 9.5 & $21.8 \mathrm{a}$ & $21.4 \mathrm{a}$ & $21.6 \mathrm{a}$ & 8.9 \\
\hline Main culm (MC) & 11.0 & 11.0 & 10.9 & 9.6 & $7.3 b$ & $21.4 \mathrm{a}$ & $22.1 \mathrm{a}$ & 8.2 \\
\hline First tiller (T1) & 10.8 & 10.7 & 10.7 & 9.6 & $21.3 \mathrm{a}$ & $9.5 \mathrm{~b}$ & $21.3 \mathrm{a}$ & 9.5 \\
\hline Second tiller (T2) & 10.4 & 10.5 & 10.3 & 9.3 & $21.6 \mathrm{a}$ & $21.6 \mathrm{a}$ & $10.8 \mathrm{~b}$ & 9.2 \\
\hline p-value of F test & 0.43 & 0.39 & 0.37 & 0.65 & 0.00 & 0.00 & 0.00 & 0.29 \\
\hline CxT interaction ( $\mathrm{p}$-value) & 0.08 & 0.07 & 0.30 & 0.62 & 0.47 & 0.19 & 0.79 & 0.09 \\
\hline CV (\%) & 6.0 & 6.7 & 5.7 & 5.3 & 30.8 & 24.3 & 31.9 & 13.9 \\
\hline Cultivar (C) & \multicolumn{3}{|c|}{ Number of grains per spike } & Average $^{(2)}$ & \multicolumn{3}{|c|}{ Grain mass per spike (g) } & Average $^{(2)}$ \\
\hline BRS Guamirim & $37.5 b$ & $35.6 \mathrm{~b}$ & $38.1 \mathrm{~b}$ & $33.1 \mathrm{~b}$ & $2.0 \mathrm{~b}$ & $1.8 \mathrm{~b}$ & $2.0 \mathrm{~b}$ & $1.6 \mathrm{~b}$ \\
\hline BRS Parrudo & $76.0 \mathrm{a}$ & $76.6 \mathrm{a}$ & $74.0 \mathrm{a}$ & $57.1 \mathrm{a}$ & $3.0 \mathrm{a}$ & $2.9 \mathrm{a}$ & $3.0 \mathrm{a}$ & $2.4 \mathrm{a}$ \\
\hline p-value of F test & 0.00 & 0.00 & 0.00 & 0.00 & 0.00 & 0.00 & 0.00 & 0.00 \\
\hline \multicolumn{9}{|l|}{ Treatment $(\mathrm{T})$} \\
\hline Control & $67.8 \mathrm{a}$ & $65.6 \mathrm{a}$ & $68.1 \mathrm{a}$ & 46.7 & $3.0 \mathrm{a}$ & $3.0 \mathrm{a}$ & $3.0 \mathrm{a}$ & 2.0 \\
\hline Main culm (MC) & $17.3 \mathrm{~b}$ & $65.8 \mathrm{a}$ & $64.0 \mathrm{a}$ & 45.4 & $0.3 \mathrm{~b}$ & $3.1 \mathrm{a}$ & $3.1 \mathrm{a}$ & 2.0 \\
\hline First tiller (T1) & $66.8 \mathrm{a}$ & $28.1 \mathrm{~b}$ & $64.8 \mathrm{a}$ & 44.6 & $3.2 \mathrm{a}$ & $0.4 \mathrm{~b}$ & $2.9 \mathrm{a}$ & 1.8 \\
\hline Second tiller (T2) & $75.3 \mathrm{a}$ & $64.9 \mathrm{a}$ & $27.4 \mathrm{a}$ & 43.6 & $3.4 \mathrm{~b}$ & $3.0 \mathrm{a}$ & $0.9 \mathrm{~b}$ & 2.0 \\
\hline p-value of F test & 0.00 & 0.00 & 0.00 & 0.54 & 0.00 & 0.00 & 0.00 & 0.63 \\
\hline CxT interaction ( $\mathrm{p}$-value) & 0.94 & 0.60 & 0.85 & 0.42 & 0.33 & 0.66 & 0.88 & 0.93 \\
\hline CV (\%) & 18.2 & 25.7 & 34.4 & 9.5 & 18.2 & 20.5 & 34.0 & 17.4 \\
\hline
\end{tabular}

${ }^{(1)}$ Means followed by equal letters in the columns do not differ, by Tukey's test, at 5\% probability. MC, main culm; T1, first tiller; T2, second tiller. ${ }^{(2)}$ Average of late tillers. 
The clethodim application on the main stems of wheat plants did not affect the length of rachis (Table 1) because the processes of the spike differentiation and expansion occurred before the herbicide application. However, clethodim affected the productive potential of the herbicide-treated stem, reducing the number of fertile spikelets, the number of grains and, consequently, the mass of grains of spike (Table 1). However, nontreated stems did not change their productive potential. Thus, in plants for which the herbicide application was performed only on the main stem leaves, the effect was observed only on that stem.
The same effect occurred for clethodim applications on the first (T1), or second (T2) tiller.

Glyphosate application to all late tillers of wheat, in the beginning of the stem elongation, resulted in a decrease of thenet carbon assimilation(A) in the primary tillers of both wheat cultivars (Figure 3). The effect of herbicide exposure was observed more clearly four days after the application on BRS Guamirim cultivar plants, and the net carbon assimilation approached zero six days after application, while on BRS Parrudo cultivar plants, the net carbon assimilation approached zero only eight days after application.
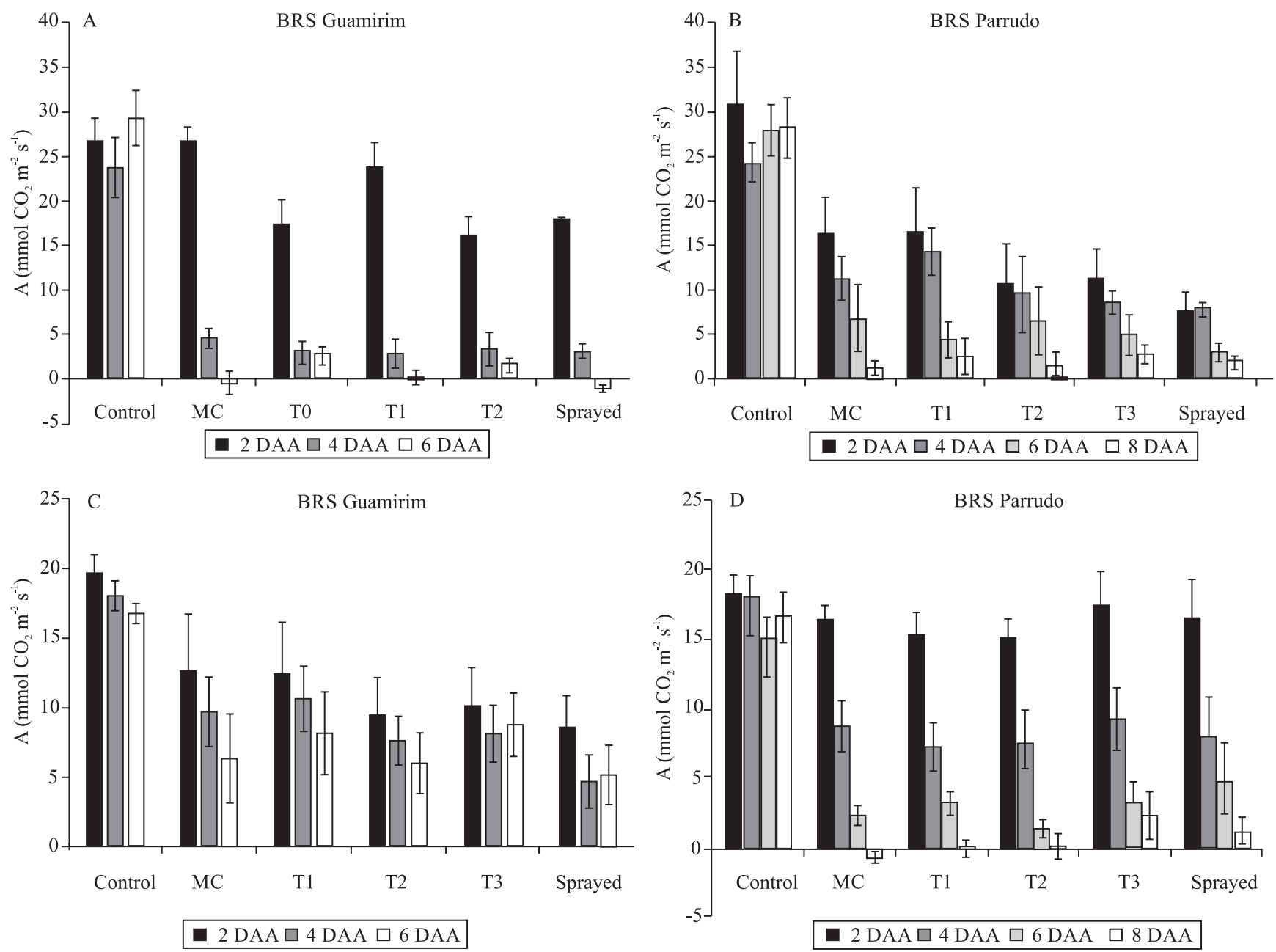

Figure 3. Carbon net assimilation of the BRS Guamirim and BRS Parrudo wheat (Triticum aestivum) cultivars as affected by glyphosate application on late tillers, at first node (A, B) and flowering (C, D) stages (Large, 1954). MC, main culm. T0, T1, T2, and T3 refer to Masle (1985) classification of wheat tillers. DAA, days after application. Vertical bars indicate standard deviation. 
The effect of glyphosate application on all late tillers of 'BRS Guamirim' plants, at the flowering stage (Figure 3), was slightly different from that observed for application during early stem elongation. The effect of herbicide application was lower during the flowering stage, especially in primary tillers not treated with herbicide. The glyphosate application on all main stems of 'BRS Parrudo', at the flowering stage, showed the same effect as that observed for application during the stem elongation period. Eight days after glyphosate application, both treated and nontreated tillers showed net carbon assimilation approaching zero.

A strong difference between the wheat cultivars was observed only when glyphosate was applied at the flowering stage, on the two late tillers (Figure 4). The main stem of 'BRS Guamirim' plants was not affected by herbicide application. However, the main stem of 'BRS Parrudo' was strongly affected by the herbicide, with the net carbon assimilation approaching zero eight days after application. For both cultivars, the two tillers treated with herbicide died six days after application.

The lack of translocation of the clethodim herbicide between treated (primary tillers) and nontreated stems was quite consistent (Table 1). Several aspects on translocation of substances related to carbohydrate metabolism or even long-distance signaling, have been addressed in the past decades (Turgeon \& Wolf, 2009; Dinant \& Lemoine, 2010; Lucas et al., 2013), being the presence of vascular connections an essential criterion for translocation. Considering that each clethodim-treated tiller is a viable tiller, it is possible to suppose that the spike of the treated-tiller was the main translocation route, since the spike is the main sink of stems. This result does not prove the absence of vascular connections among wheat stems, but it clearly shows the direction of translocation between sources and sinks in the stem. It is important to highlight that metabolites associated with long-distance signaling throughout the plant do not necessarily follow the movement of photoassimilates (Dinant \& Lemoine, 2010; Lucas et al., 2013), although the translocation of the herbicide occurred by this route in the present study.

With the use of glyphosate in late tillers, some aspects were shown on the movement of assimilates among stems of wheat plants. The reduction of net carbon assimilation in primary tillers not treated with glyphosate indicates the existence of vascular connections among stems, both in the stem elongation period and in the flowering period (Figure 3). This response was observed regardless of the tillering potential of each cultivar, although it was less intense for BRS Guamirim during the flowering stage. This is an interesting aspect to be considered, since the amount of active ingredient applied to BRS Guamirim plants was higher, despite this cultivar's higher number of tillers (Figure 2). The number of stems not treated with glyphosate was the same for both cultivars.

The most surprising result was observed when glyphosate was applied only on the last two tillers, and the net carbon assimilation was measured on the main stem of each plant. The main stem of 'BRS Parrudo' was significantly affected by glyphosate, while the net carbon assimilation remained constant in the main stem of 'BRS Guamirim' (Figure 4). Fioreze et al. (2019) found that 'BRS Parrudo' plants show higher biometric and productive uniformity among tillers than 'BRS Guamirim', under a freetillering and protected cultivation. Adding these aspects to the results obtained in the present study, it is possible to state that the translocation of solutes among wheat stems varies depending on the degree of

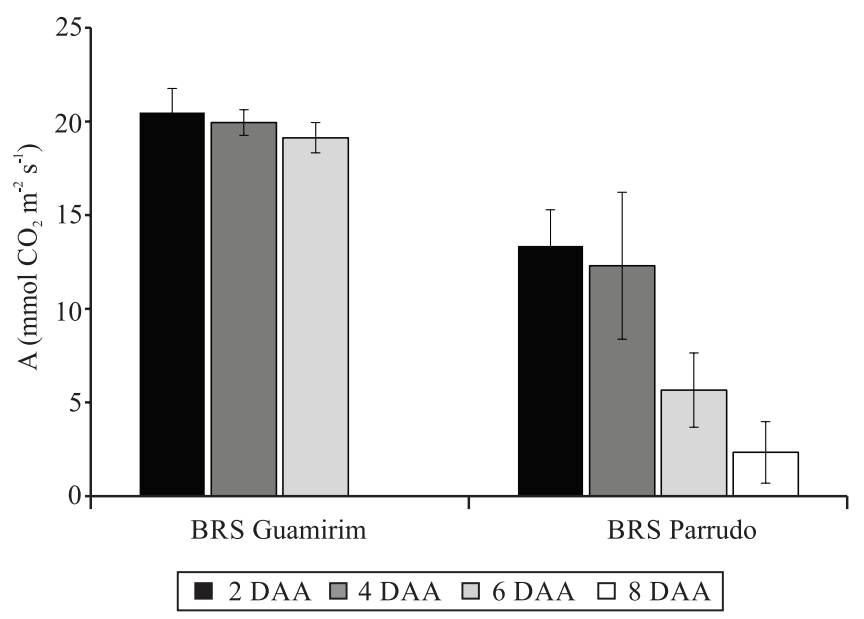

Figure 4. Carbon net assimilation of main culm of BRS Guamirim and BRS Parrudo wheat (Triticum aestivum) cultivars as affected by glyphosate application on two last tillers emitted at the 10.1 (first node) stage of Feeks scale. DAA, days after application. Vertical bars indicate standard deviation. 
development of a given tiller in relation to the others. Therefore, the translocation could be more effective among well-formed stems, with low possibility of translocation among senescent, malformed tillers. This would refute the thought that late, nonproductive tillers could be transient sinks that supply the grain filling of other stems under limiting environmental conditions.

\section{Conclusions}

1. Well-developed late tillers show higher potential for the translocation of assimilates to the whole wheat (Triticum aestivum) plant than poor-developed late tillers.

2. Wheat plants show a low potential for translocation of assimilates from primary to secondary tillers.

3. There is translocation of assimilates from secondary tillers to the whole plant.

\section{References}

AHMADI, A.; JOUDI, M.; JANMOHAMMADI, M. Late defoliation and wheat yield: Little evidence of post-anthesis source limitation. Field Crops Research, v.113, p.90-93, 2009. DOI: https://doi.org/10.1016/j.fcr.2009.04.010.

ALVES, A.C.; MUNDSTOCK, C.M.; MEDEIROS, J. de D. Sistema vascular e controle do desenvolvimento de perfilhos em cereais de estação fria. Revista Brasileira de Botânica, v.23, p.59-67, 2000. DOI: https://doi.org/10.1590/S010084042000000100007.

BROMILOW, R.H.; CHAMBERLAIN, K.; EVANS, A.A. Physicochemical aspects of phloem translocation of herbicides. Weed Science, v.38, p.305-314, 1990. DOI: https://doi.org/10.1017/ S0043174500056575.

BURTON, J.D.; GRONWALD, J.W.; SOMERS, D.A.; CONNELLY, J.A.; GENGENBACH, B.G.; WYSE, D.L. Inhibition of plant acetyl-coenzyme a carboxylase by the herbicides sethoxydim and haloxyfop. Biochemical and Biophysical Research Communications, v.148, p.1039-1044, 1987. DOI: https://doi.org/10.1016/S0006-291X(87)80236-X.

DINANT, S.; LEMOINE, R. The phloem pathway: new issues and old debates. Comptes Rendus Biologies, v.333, p.307-319, 2010. DOI: https://doi.org/10.1016/j.crvi.2010.01.006.

DODIG, D.; RANČIĆ, D.; VUCELIĆ RADOVIĆ, B.; ZORIĆ, M.; SAVIĆ, J.; KANDIĆ, V.; PEĆINAR, I.; STANOJEVIĆ, S.; ŠEŠLIJA, A.; VASSILEV, D.; PEKIĆ-QUARRIE, S. Response of wheat plants under post-anthesis stress induced by defoliation: II. Contribution of peduncle morpho-anatomical traits and carbon reserves to grain yield. Journal of Agricultural Science, v.155, p.475-493, 2017. DOI: https://doi.or/10.1017/ S0021859616000551.
DRECCER, M.F.; CHAPMAN, S.C.; RATTEY, A.R.; NEAL, J.; SONGH, Y.; CHRISTOPHER, J.J.T.; REYNOLDS, M. Developmental and growth controls of tillering and watersoluble carbohydrate accumulation in contrasting wheat (Triticum aestivum L.) genotypes: can we dissect them? Journal of Experimental Botany, v.64, p.143-160, 2013. DOI: https://doi.org/10.1093/jxb/ers317.

DUGGAN, B.L.; RICHARDS, R.A.; VAN HERWAARDEN, A.F. Agronomic evaluation of a tiller inhibition gene (tin) in wheat. II. Growth and partitioning of assimilate. Australian Journal of Agricultural Research, v.56, p.179-186, 2005. DOI: https://doi.org/10.1071/AR04153.

FERREIRA, D.F. Sisvar: a computer statistical analysis system. Ciência e Agrotecnologia, v.35, p.1039-1042, 2011. DOI: https://doi.or/10.1590/S1413-70542011000600001.

FIOREZE, S.L.; VACARI, J.; TUREK, T.L.; MICHELON, L.H.; DRUN, R.P. Componentes produtivos do trigo em função da temperatura no período de diferenciação de espiguetas. Revista de Ciências Agroveterinárias, v.18, p.24-32, 2019. DOI: https://doi.or/10.5965/223811711812019024.

GUO, Z.; SCHNURBUSCH, T. Variation of floret fertility in hexaploid wheat revealed by tiller removal. Journal of Experimental Botany, v.66, p.5945-5958, 2015. DOI: https://doi.or/10.1093/jxb/erv303.

HENDRIKS, P.W; KIRKEGAARD, J.A.; LILLEY, J.M.; GREGORY, P.J.; REBETZKE, G.J. A tillering inhibition gene influences root-shoot carbon partitioning and pattern of water use to improve wheat productivity in rainfed environments. Journal of Experimental Botany, v.67, p.327-340, 2016. DOI: https://doi.or/10.1093/jxb/erv457.

HOUSHMANDFAR, A.; REBETZKE, G.J.; LAWES, R.; TAUSZ, $M$. Grain yield responsiveness to water supply in near-isogenic reduced-tillering wheat lines - An engineered crop trait near its upper limit. European Journal of Agronomy, v.102, p.33-38, 2019. DOI: https://doi.or/10.1016/j.eja.2018.11.003.

LARGE, E.C. Growth stages in cereals illustration of the Feeks scales. Plant Pathology, v.3, p.128-129, 1954. DOI: https://doi.or/10.1111/j.1365-3059.1954.tb00716.x.

LUCAS, W.J.; GROOVER, A.; LICHTENBERGER, R.; FURUTA, K.; YADAV, S.-R.; HELARIUTTA, Y.; HE, X.-Q.; FUKUDA, H.; KANG, J.; BRADY, S.M.; PATRICK, J.W.; SPERRY, J.; YOSHIDA, A.; LÓPEZ-MILLÁN, A.-F.; GRUSAK, M.A.; KACHROO, P. The plant vascular system: evolution, development and functions. Journal of Integrative Plant Biology, v.55, p.294388, 2013. DOI: https://doi.or/10.1111/jipb.12041.

MASLE J. Competition among tillers in winter wheat: consequences for growth and development of the crop. In: DAY, W.; ATKIN, R.K. (Ed.). Wheat Growth and Modelling. New York: Springer, 1985. p.33-54. DOI: https://doi.org/10.1007/978-14899-3665-3_4.

MITCHELL, J.H.; CHAPMAN, S.C.; REBETZKE, G.J.; BONNETT, D.G.; FUKAI, S. Evaluation of a reduced-tillering (tin) gene in wheat lines grown across different production environments. Crop and Pasture Science, v.63, p.128-141, 2012. DOI: https://doi.org/10.1071/CP11260. 
MITCHELL, J.H.; REBETZKE, G.J.; CHAPMAN, S.C.; FUKAI, $\mathrm{S}$. Evaluation of reduced-tillering (tin) wheat lines in managed, terminal water deficit environment. Journal of Experimental Botany, v.64, p.3439-3451, 2013. DOI: https://doi.org/10.1093/jxb/ ert181.

NANDULA, V.K.; POSTON, D.H.; REDDY, K.N.; KOGER, C.H. Formulation and adjuvant effects on the absorption and translocation of ${ }^{14} \mathrm{C}$-clethodim in wheat (Triticum aestivum L.). Weed Biology and Management, v.7, p.226-231, 2007. DOI: https://doi.org/10.1111/j.1445-6664.2007.00260.x.

RUAN, Y.; HU, Y.; SCHMIDHALTER, U. Effect of tiller removal on ion content in mainstem and subtillers of spring wheat under moderate salinity. Journal of Plant Nutrition, v.35, p.1314-1328, 2012. DOI: https://doi.org/10.1080/01904167.2012.684124.

SANTOS, H.G. dos; JACOMINE, P.K.T.; ANJOS, L.H.C. dos; OLIVEIRA, V.Á. de; LUMBRERAS, J.F.; COELHO, M.R.; ALMEIDA, J.A. de; ARAÚJO FILHO, J.C. de; OLIVEIRA, J.B. de; CUNHA, T.J.F. Sistema brasileiro de classificação de solos. 5.ed. rev. e ampl. Embrapa: Brasília, 2018.
SLEWINSKI, T.L.; ZHANG, C.; TURGEON, R. Structural and functional heterogeneity in phloem loading and transport. Frontiers in Plant Science, v.4, art.244, 2013. DOI: https://doi.org/10.3389/fpls.2013.00244.

TARDIF, F.J.; LEROUX, G.D. Translocation of glyphosate and quizalofop and metabolism of quizalofop in quackgrass biotypes (Elytrigia repens). Weed Technology, v.5, p.525-531, 1991. DOI: https://doi.org/10.1017/S0890037X00027275.

TUREK, T.L.; MICHELON, L.H.; TOCHETTO, C.; COELHO, A.E.; FIOREZE, S.L. Consumo de água e eficiência produtiva de plantas de trigo tratadas com etil-trinexapac. Revista de Ciências Agroveterinárias, v.17, p.198-205, 2018. DOI: https://doi.org/10.5965/223811711722018198.

TURGEON, R.; WOLF, S. Phloem transport: cellular pathways and molecular trafficking. Annual Review of Plant Biology, v.60, p.207-221, 2009. DOI: https://doi.org/10.1146/annurev. arplant.043008.092045. 